\title{
An $E$. coli SOS-EGFP biosensor for fast and sensitive detection of DNA damaging agents
}

\author{
Zhilan Chen, Meiling Lu, Dandan Zou, Hailin Wang* \\ Research Center for Eco-Environmental Sciences, Chinese Academy of Sciences, Beijing 100085, China. E-mail: hlwang@rcees.ac.cn
}

Received 25 February 2011; revised 25 April 2011; accepted 09 May 2011

\begin{abstract}
An E. coli SOS-EGFP biosensor which expresses enhanced green fluorescent protein as a reporter protein under the control of recA gene promoter in SOS response was constructed for detection of DNA damage and evaluation of DNA damaging chemicals. The chemicals that may cause substantial DNA damage will trigger SOS response in the constructed bacterial biosensor, and then the reporter $e g f p$ gene under the control of recA promoter is stimulated to express as a fluorescent protein, allowing fast and sensitive fluorescence detection. Interestingly, this biosensor can be simultaneously applied for evaluation of genotoxicity and cytotoxicity. The SOS-EGFP bacterial biosensor provides a sensitive, specific and simple method for detecting known and potential DNA damaging chemicals.
\end{abstract}

Key words: bacterial biosensor; detection; DNA damage; genotoxins; SOS response

DOI: $10.1016 / \mathrm{S} 1001-0742(11) 60722-5$

\section{Introduction}

DNA damage may occur at nucleotide level, strand level, chromosome level and genome level, and can be present as unusual modifications of nucleotides (alkylation, oxidation, adducts formation and abnormal methylation), strand break (single strand break and double strand break), crosslinking (inner-strand and intra-strand with DNA), micronucleus, abnormality of chromosome number and so on (Friedberg et al., 2006). DNA damage will affect DNA replication, repair and gene expression, and may be mutagenetic to cells and further carcinogenesis in organisms.

Various chemicals, endogenous genomic defects and environmental factors can cause damage to genomic DNA (Arshad et al., 2010; Park et al., 2005; Risom et al., 2003). DNA damaging agents include the existed materials on the earth, for example, the unstable isotopes, and newly found or manmade chemicals, such as anticancer drugs.

With the large-scale production and use of chemicals, the toxicology of newly-produced chemicals and possible by-products should be provided, particularly for genotoxicity, mutagenicity and carcinogenicity (Ohe et al., 2004). In practical application, the concentrations of some DNA damaging agents, such as germicide (hydrogen peroxide with concentration of $1.0 \mathrm{~mol} / \mathrm{L}$, Doughty, 1990) and antibiotics (mitomycin $\mathrm{C}$ with concentration of $1.5 \mathrm{mmol} / \mathrm{L}$, Hamza et al., 2005) are required to be high enough to kill their targets (microbial infectors and cancer cells

\footnotetext{
* Corresponding author. E-mail: hlwang@rcees.ac.cn
}

respectively). However, these agents may also be harmful to the disinfecting operators or the normal organs of treated patients especially for a long period of use. In most cases, the potential DNA damaging agents are exposed at low concentrations but with a long period of time in the environment. Therefore, the detection methods of highsensitivity, high-throughput and low cost are of intensive interest. A number of methods have been developed for detection of DNA damage and DNA damaging agents. High sensitive separation methods combined with qualitative analytical technologies have been utilized to detect the DNA damage in terms of unique biomarkers such as oxidative DNA damage and stable DNA adducts. These analytical methods include HPLC-EC (Rodríguez-Ariza et al., 1999), LC-GC-MS (Cooke et al., 2006), LC-MS/MS (Feng et al., 2008) and UPLC-MS/MS (Feng et al., 2009), ultrasensitive CE-LIF immunoassay (Wang et al., 2009, 2010) and ${ }^{32}$ P-post labeling test (Dunn et al., 1987; Funk et al., 2010). Although they can quantify or quantitate the known DNA damage and/or DNA damaging agents, it is challenging for these methods to be applied to detection and screening of unknown and potential DNA damaging agents, more challenging, for genotoxic chemical mixture.

To detect unknown DNA damaging agents and to evaluate the related DNA damage potency, a biological response SOS response which may occur in various bacteria is exploited to develop a novel type of biosensor for this purpose. In prokaryotes, SOS response will occur when their cells suffering from substantial DNA damage. During normal growth, cells undergo little DNA damage and SOS genes are negatively regulated by LexA repressor protein. 
The LexA protein binds to a consensus sequence (the SOS box) in the promoter region for those SOS genes. When DNA damage arises, the DNA replication will be blocked at DNA damage sites. Therefore, large mounts of singlestrand DNA will appear which needs more RecA protein to bind to. The resulted RecA-ssDNA filaments provide the activated form RecA protein which interacts with the LexA repressor to facilitate the LexA repressor's self-cleavage from the SOS promoters (Nelson and Cox, 2005; Friedberg et al., 2006). At the early stage of SOS response, RecA protein can enhance its amount significantly for several times. Because the amount of RecA protein is closely related with the activity of $r e c A$ promoter, the reporter EGFP protein under the control of recA promoter can manifest the expression of RecA protein. The fluorescence of EGFP protein can easily be tested by a fluorometer, so the fluorescent intensity can representative the activity of recA promoter, further displaying the level of SOS response of cells treated by chemicals.

The expressed EGFP protein from reporter gene displays 35-times enhanced fluorescence signal over the wild type green fluorescent protein (wtGFP) due to the double mutation of Phe64Leu and Ser65Thr (Cormack et al., 1996). And the EGFP protein gets increased fluorescence intensity and photostability, enhanced $37^{\circ} \mathrm{C}$ folding efficiency and the same excitation and emission peaks with FITC, which makes more general researcher for practical use of EGFP protein (Heim et al., 1995; Cormack et al., 1996). In addition, the EGFP protein needs only oxygen to emit fluorescence without exogenous substrates or cofactors while enzymatic (such as beta-galactosidase) and lux reporters need reaction with other substrates to produce detectable signal with increasing cost, especially at large scale detection of chemicals (Miller, 1972; Vollmer et al., 1997).

In the present study, we constructed a bacterial biosensor in an E. coli strain with a transformed egfp gene as a reporter gene under the control of the promoter of recA gene, and developed an SOS-EGFP test. By this test, the biosensor cells treated by chemicals can produce brighter fluorescence than the untreated control if the chemicals can induce substantial DNA damage. We discard the complicated procedure of sample preparation and separation, and provide an easy, speedy and reproducible assay to screen the DNA damaging agents.

\section{Materials and methods}

\subsection{Bacterial strains and culture conditions}

All E. coli bacterial strains grew in the LB medium (pH 7.4). The LB medium was prepared with $10 \mathrm{~g}$ bacterial peptone (BD Biosciences, USA), $5 \mathrm{~g}$ yeast extract (BD Biosciences, USA), $5 \mathrm{~g} \mathrm{NaCl}, 15-20 \mathrm{~g}$ agar if used for solid medium, and $1000 \mathrm{~mL} \mathrm{H}_{2} \mathrm{O}$ (containing $60 \mu \mathrm{g} / \mathrm{mL}$ ampicillin or $40 \mu \mathrm{g} / \mathrm{mL}$ kanamycin if necessary). For $\log$ phase bacteria culture, the bacterial mono-clone grown on the LB agar plate was inoculated into proper volume of LB liquid medium and was incubated at $37^{\circ} \mathrm{C}$ overnight.
After dilution $(1: 50, V: V)$ in fresh LB medium, the culture was incubated at $37^{\circ} \mathrm{C}$ until the optical density at $600 \mathrm{~nm}$ $\left(\mathrm{OD}_{600}\right)$ reached 0.2 to 0.4 . This procedure may take about 2-3 hr at $130 \mathrm{r} / \mathrm{min}$ at $37^{\circ} \mathrm{C}$. The bacterial strains and plasmids used in this study are listed in Table S1.

\subsection{Molecular cloning and construction of BPE strain}

E. coli BL21(DE3)/pETEGFP (BPE strain) was obtained by genetic engineering. The egfp gene was obtained from pEGFP-C1 plasmid by polymerase chain reaction (PCR) amplification. PCR amplification were performed by using a NdeI containing forward primer $\left(5^{\prime}\right.$ GGAATTCcatatgATGGTGAGCAAGGGCGAGGA-3' $)$ and a BamHI containing reverse primer (5'AACGggatccGAGCTCGAGATCTGAGTCC-3'). The amplification procedure was as follows: predenatured at $95^{\circ} \mathrm{C}$ for $4 \mathrm{~min}, 30$ cycles with denaturation at $95^{\circ} \mathrm{C}$ for $45 \mathrm{sec}$, annealing at $55^{\circ} \mathrm{C}$ for $45 \mathrm{sec}$, extension at $74^{\circ} \mathrm{C}$ for $50 \mathrm{sec}$, with a final extension at $74^{\circ} \mathrm{C}$ for $5 \mathrm{~min}$.

The pET-16b vector contained a T7 promoter, a multiple cloning site for expression of the cloned protein gene with a His-tag, and an ampicillin resistant gene for selection and amplification in E. coli cells. The pET-16b vector and a fragment of amplified egfp gene were double-enzymatic digested with $N d e \mathrm{I}$ and $\mathrm{BamHI}$, and then the two fragments were ligated. The resulted pETEGEP vector was utilized for verification of EGFP protein expression in BL21 (DE3) cells. The positive transformants were screened by ampicillin resistant and confirmed by colonial PCR. Colonial PCR amplification was performed by using a forward primer (5'-TAATACGACTCACTATAGGGG-3') and a reverse primer (5'-GCTAGTTATTG CTCAGCG-3').

\subsection{Molecular cloning and construction of B5 strain}

E. coli BL21(DE3)/pETPrecAegfp5 (B5 strain) was obtained also by genetic engineering. The $E$. coli B5 strain expresses EGFP protein under the control of recA promoter. The fragment of recA promoter was amplified by PCR using E. coli K12 ER2925 genomic DNA as a template. The recA promoter is a DNA fragment of $250 \mathrm{bp}$ long upstream of the recA gene open reading frame, including the ribosomal binding site and TATA box. PCR amplification was performed by using a $B g l$ II containing forward primer (5'-AGGAagatctGGCAGTGAAGAGAAGCCTGT-3') and an NcoI containing reverse primer $\left(5^{\prime}\right.$ CATGccatggTTACTCCTGTCATGCCGGGT-3'). PCR was performed according to the following program: predenatured at $94^{\circ} \mathrm{C}$ for $3 \mathrm{~min}$, then 30 cycles of $94^{\circ} \mathrm{C}$ for $45 \mathrm{sec}, 55^{\circ} \mathrm{C}$ for $45 \mathrm{sec}, 72^{\circ} \mathrm{C}$ for $30 \mathrm{sec}$, with a final $5 \mathrm{~min}$ elongation step at $72^{\circ} \mathrm{C}$.

The $\mathrm{pET}-16 \mathrm{~b}$ vector was digested with double-enzyme of $B g l \mathrm{II} / \mathrm{NcoI}$ to remove the T7 promoter and named pET$16 \mathrm{~b}:: \mathrm{P}_{\mathrm{T}^{-}}$vector. Then the double-enzyme digested recA promoter was ligated into the $\mathrm{pET}-16 \mathrm{~b}:: \mathrm{P}_{\mathrm{T} 7^{-}}$vector and the recombinant is named as $\mathrm{pET}-16 \mathrm{~b}:: \mathrm{P}_{\mathrm{T} 7^{-}}::$PrecA vector. The $e g f p$ gene from pEGFP-C1 plasmid was ligated into the NdeI/BamHI site of $\mathrm{pET}-16 \mathrm{~b}:: \mathrm{P}_{\mathrm{T} 7^{-}}:: \mathrm{Prec} A$ vector. The ligated product of egfp gene and $\mathrm{pET}-16 \mathrm{~b}:: \mathrm{P}_{\mathrm{T}^{-}}:: \mathrm{P} r e c A$ 
vector was transformed into the subcloning strain $E$. coli DH5a. The positive transformants were screened by ampicillin resistant and confirmed by colonial PCR. Colonial PCR amplification was performed by using a forward primer (5'-GGCAGTGAAGAGAAGCCTGT-3') and a reverse primer (5'-GCTAGTTATTGCTCAGCG-3'). The PCR was performed as the following conditions: predenatured at $95^{\circ} \mathrm{C}$ for 4 min, 30 cycles with denaturation at $95^{\circ} \mathrm{C}$ for $45 \mathrm{sec}$, annealing at $52^{\circ} \mathrm{C}$ for $45 \mathrm{sec}$, extension at $72^{\circ} \mathrm{C}$ for $1 \mathrm{~min}$, with a final extension at $72^{\circ} \mathrm{C}$ for $5 \mathrm{~min}$. The recombined vector was extracted from $E$. coli DH5a and transformed into the protein-expressing strain $E$. coli BL21 (DE3).

PCR was performed using a MyCycler Personal Thermal Cycler (BioRad, USA). The synthesis of primers and the sequencing of insertion DNA fragments were performed in Sangon, Shanghai, China. Restricition enzymes were purchased from New England, Biolabs, Co. And DNA ligation was operated using Rapid DNA Ligation Kit (Fermentas, CA). And DNA (and plasmids) extraction, purification, digestion, transformation, electrophoresis and buffer preparation were performed according to the Molecular Cloning handbook (Sambrook and Russell, 2001) or the instructions of commercial kits (Tiangen, Co. Beijing, China).

\subsection{Bacterial induction}

Aliquots of BPE cells $(0.18 \mathrm{~mL})$ of steady phase were induced by isopropyl $\beta$-D-1-thiogalactopyranoside (IPTG) with $0,0.1$ and $0.2 \mathrm{mmol} / \mathrm{L}$ for verification of the expression and function of EGFP protein in E. coli cells.

Aliquots of B5 cells of $\log$ phase were used for the SOS-EGFP test. Aliquots $(0.18 \mathrm{~mL})$ of the $\log$ phase culture cells were transferred into $0.6 \mathrm{~mL}$ tubes, and 20 $\mu \mathrm{L}$ of appropriate concentrations of the test compound in aqueous solution was added. The $20 \mu \mathrm{L}$ of distilled water was added to the control tubes. The cells were incubated and induced at $37^{\circ} \mathrm{C}$ for $2 \mathrm{hr}$ at $130 \mathrm{r} / \mathrm{min}$. Experiments were performed three times, and the standard errors between the experiments were determined.

\subsection{Fluorescent microscopy analysis}

The fluorescence images of bacterial cells were obtained by confocal laser scanning microscope consisted of a Leica DMI 6000B inverted microscope $(100 \times$ oil immersion objective, 1.40 numerical aperture NA) and a Leica TCS SP5 confocal scanning system. The fluorescence of $E$. coli cells were excited by $488 \mathrm{~nm}$ line of an argon ion laser (4.5 $\mathrm{mW}$ ), and the emission was detected by a photomultiplier tube (PMT) at 500 to $560 \mathrm{~nm}$. The PMT voltage was set at $890 \mathrm{~V}$. The bright-field images were acquired at the same time with a PMT gain of $340 \mathrm{~V}$. Each image was taken from a physical dimension of $155 \mu \mathrm{m} \times 155 \mu \mathrm{m}$.

\subsection{Fluorescence spectral scanning}

The E. coli cells were excited at $480 \mathrm{~nm}$ and the fluorescence was scanned from 500 to $600 \mathrm{~nm}$ in 96-well plate (Corning, USA) with spectral scanning multimode reader (VarioskanßFlash, Thermo, USA) at room temperature.
The cell density $\left(\mathrm{OD}_{600}\right)$ was determined simultaneously using the same device.

\subsection{Chemicals for SOS-EGFP test}

Typical genotoxins including mitomycin $\mathrm{C}$ (MMC), Nmethyl- $\mathrm{N}^{\prime}$-nitro-N-nitrosoguanidine (MNNG), nalidixic acid (NA), formaldehyde $\left(\mathrm{CH}_{2} \mathrm{O}\right)$ and hydrogen peroxide $\left(\mathrm{H}_{2} \mathrm{O}_{2}\right)$ were tested. The following reagents with varied concentrations were used in the assay: 1 to $500 \mathrm{nmol} / \mathrm{L}$ MMC (Inalco, USA), 0.1 to $10 \mu \mathrm{mol} / \mathrm{L}$ MNNG (AccuStandard, USA), 0.1 to $8 \mu \mathrm{mol} / \mathrm{L}$ NA (Sigma, USA), 10 $\mu \mathrm{mol} / \mathrm{L}$ to $10 \mathrm{mmol} / \mathrm{L} \mathrm{H}_{2} \mathrm{O}_{2}$ (Beijing Chemical Works, China) and $10 \mu \mathrm{mol} / \mathrm{L}$ to $1 \mathrm{mmol} / \mathrm{L} \mathrm{CH}_{2} \mathrm{O}$ (Sigma, USA). Furthermore, 1 to $100 \mu \mathrm{mol} / \mathrm{L}$ kanamycin sulfate (KAN) (Amresco, USA), 1 to $100 \mathrm{mmol} / \mathrm{L}$ acetone (AC) (Beijing Chemical Works, China), 1 to $100 \mathrm{mmol} / \mathrm{L} n$-butanol (BUT) (Beijing Chemical Works, China) and 0.1 to 10 $\mathrm{mmol} / \mathrm{L}$ phenol (PHE) (Beijing Chemical Works, China) were used as negative controls.

\subsection{Data analysis}

The $\mathrm{OD}_{x} / \mathrm{OD}_{0}$ is defined as the ratio of optical density at $600 \mathrm{~nm}\left(\mathrm{OD}_{600}\right)$ of treated sample and untreated control sample at the same induction time point. The specific fluorescent unit (SFU) is calculated as the tested fluorescence intensity divided by $\mathrm{OD}_{600}$ of the same sample. Induction factor $\left(F_{\mathrm{i}}\right)$ is the ratio of SFU value of treated sample and the SFU value of untreated sample $\left(\mathrm{SFU}_{x} / \mathrm{SFU}_{0}\right)$ (Norman et al., 2005). Though various criteria have been used to assess the genotoxicity of chemicals (Quillardet and Hofnung, 1993), we utilized induction factor $\left(F_{\mathrm{i}}\right)$ to evaluate the genotoxicity of tested chemicals. If the value of $F_{\mathrm{i}}$ reaches 2 or more at any concentrations, it means the tested compounds were considered to be DNA damaging agents or genotoxic. The low limit of detection is defined as the dose at which the induction factor reaches the value as twice as that of the background (Mersch-Sundermann et al., 1994). Experiments were performed at least three times, and the standard deviations between the experiments were determined.

\section{Results and discussion}

\subsection{Characterization and analysis of the cloned $e g f p$ gene}

As egfp gene expressed in pET vectors (Novagen) has the possibility to form inclusion body in the protein expression strain (Verkhusha et al., 2001; Cabanne et al., 2005), it is necessary to investigate if eukaryotic egfp gene can be well expressed and has right function in prokaryotic $E$. coli cells and whether pET-16b vector can be used for its expression. egfp gene from plasmid pEGFP-C1 was cloned through PCR amplification and subcloned into pET-16b. The resulted pETEGFP plasmid was transformed into E. coli DH5a for positive recombinant selection. All the randomly screened E. coli monocolonies from the LB (ampicillin) agar plates were examined by colonial PCR for exponential amplification of the inserted egfp fragment. Agarose gel 
electrophoresis analysis of the amplified DNA products (Fig. 1) showed that it indeed appeared and had a right length (952 bp) as same as that of template fragment (total length of primers, egfp gene and plasmid fragment) while no right amplified product was observed for the blank vector, confirming the insertion of egfp gene into the vector. The inserts were further characterized by sequencing both strands of the vectors in the regions between $\mathrm{T} 7$ promoter primer site and $\mathrm{T} 7$ terminator primer site. The sequencing results clearly showed that the inserted fragment showed $100 \%$ homologue sequence with the template (omitting the primer modifications containing the restriction sites) and the right direction (Fig. S1), confirming the correct insertion of the egfp gene in pET-16b vector.

The pETEGFP vector was transformed into a high expression strain E. coli BL21(DE3) and the resultant cells

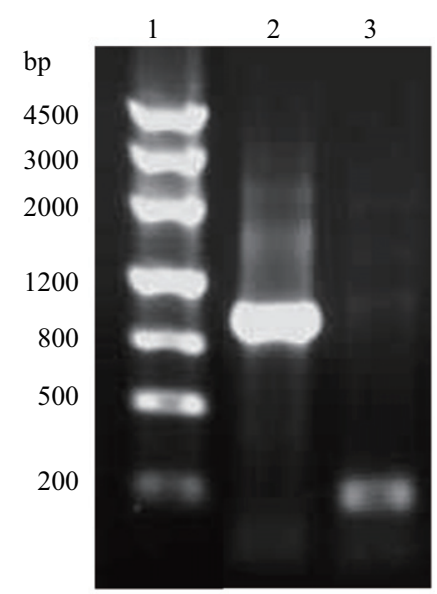

Fig. 1 Identification of inserted egfp gene in recombinant pETEGFP plasmid by agarose gel electrophoresis. Lanes 1 is DNA marker, and lanes 2 and 3 are amplified products by colonial PCR from positive recombinant pETEGFP vector and blank vector, respectively. Electrophoresis conditions: $0.8 \%$ agarose gel, $1 \times$ TBE buffer, $4 \mathrm{~V} / \mathrm{cm}, 40 \mathrm{~min}$. was named as BPE strain. The cells grew to steady phase and were induced by IPTG. Through fluorescent microscopic observation, it was found that strong fluorescence signal could be detected and imaged from the BPE strain in response to the IPTG induction (Fig. 2). It is evident that the fluorescence of BPE cells enhanced significantly upon the increase of induction concentration of IPTG (Fig. 2). These results suggest the feasibility to express the EGFP protein in E. coli BL21(DE3). The observed fluorescence signal also reflects the fact that the expressed EGFP protein can be correctly folded in its native conformation. In the pET-16b vector a His-tag is connected with the N-terminal of recombinant protein. The observed strong fluorescence signal of EGFP may also indicate that the His-tag does not affect the conformation and function of the fused EGFP protein in the SOS-EGFP host bacterial strain.

\subsection{Expression and function of the fused $\operatorname{rec} A$ promoter-egfp gene}

With the accomplishment of the correct expression and function of recombinant egfp gene in E. coli BL21(DE3) cells, we further investigate the construction of fused recA promoter-egfp gene in plasmid pET-16b and its expression and function in E. coli BL21(DE3) cells. Agarose gel electrophoresis analysis showed that the amplified recA promoter fragment can be detected in pET$16 \mathrm{~b}:: \mathrm{P}_{\mathrm{T}^{-}}::$PrecA plasmid and has a correct length of 397 bp (total length of primers, recA promoter and plasmid fragments) through colonial PCR amplification (Fig. 3a). Note that in colonial PCR amplification, upstream primer of recA promoter of inserted fragment and $\mathrm{T} 7$ terminator primer on $\mathrm{pET}-16 \mathrm{~b}$ plasmid were used for enhancing the specific amplification of inserted fragments in recombinant plasmids. The DNA fragment of fused recA promoter-egfp gene could be observed in pET-16b:: $\mathrm{P}_{\mathrm{T}^{-}}::$PrecA vector (Fig. 3a) and also have a correct length of $1100 \mathrm{bp}$,
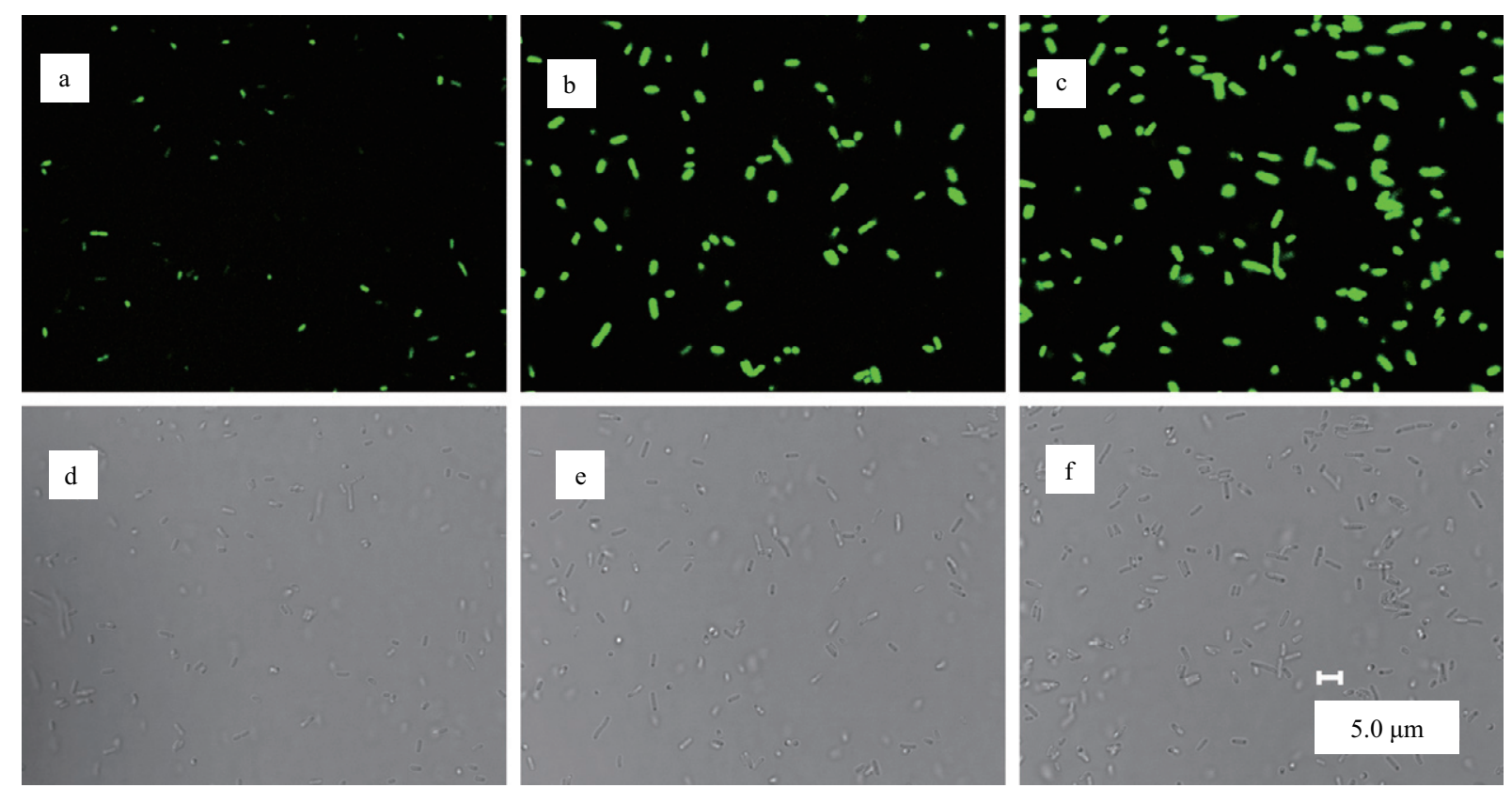

Fig. 2 Expression of egfp gene from pETEGFP vector in BPE cells upon IPTG induction. The BPE cells expressing EGFP protein were fluorescence imaged by confocal laser-scanning microscopy. The cells were not induced (a), or induced by $0.1 \mathrm{mmol} / \mathrm{L} \mathrm{IPTG} \mathrm{(b)} \mathrm{or} \mathrm{0.2} \mathrm{mmol/L} \mathrm{IPTG} \mathrm{(c).} \mathrm{The}$ corresponding images at bright field are shown in (d), (e) and (f), respectively. 

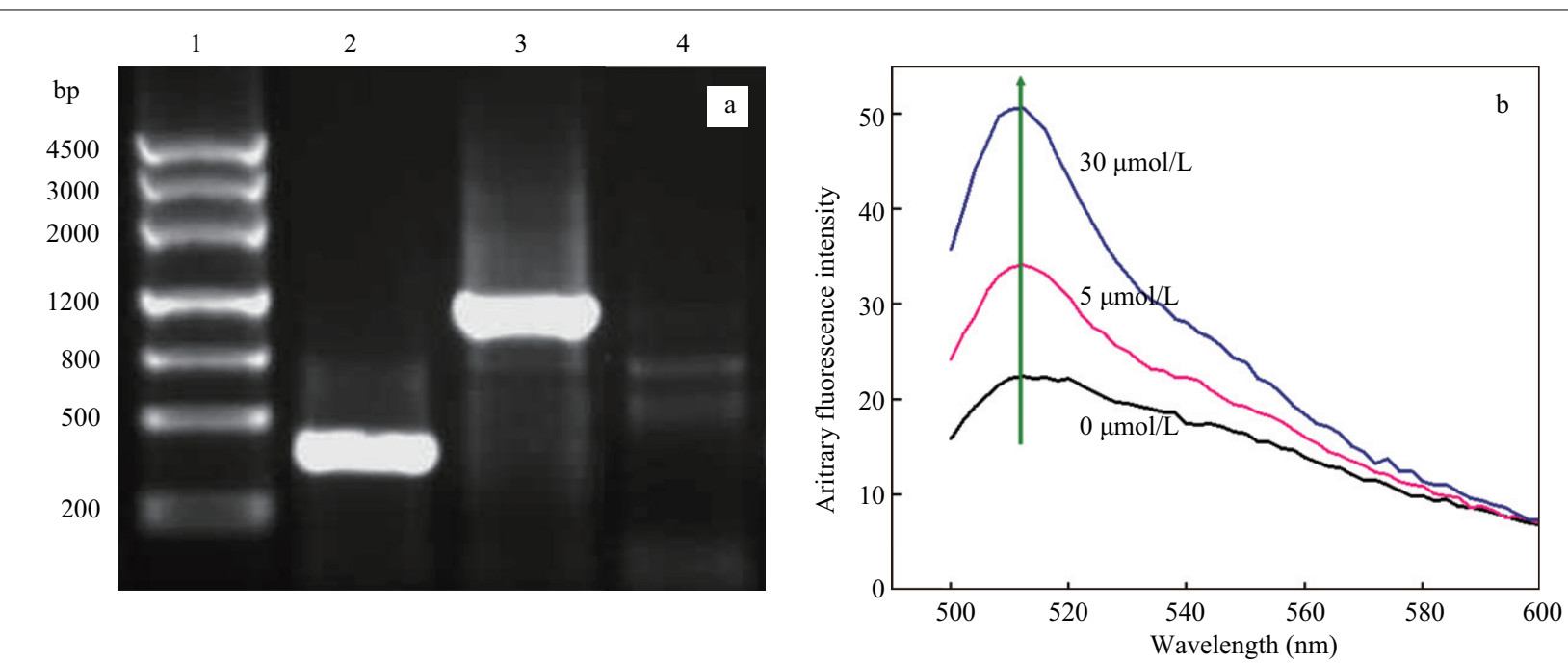

Fig. 3 Identification of function of the fused $r e c A$ promoter-egfp gene in recombinant vector by agarose gel electrophoresis and fluorescence spectra scanning. (a) DNA marker/bp (lane 1), recA promoter in pET-16b:: $\mathrm{P}_{\mathrm{T} 7^{-}}:$PrecA vector (lane 2), and fused recA promoter-egfp in pET16b:: $\mathrm{P}_{\mathrm{T}^{-}}::$PrecA::egfp vector (lane 3), blank vector (lane 4). Electrophoresis conditions: $0.8 \%$ agarose gel, $1 \times \mathrm{TBE}$ buffer, $4 \mathrm{~V} / \mathrm{cm}, 40 \mathrm{~min}$. (b) B5 strain cells grew to $\log$ phase and were induced by $0,5 \mu \mathrm{mol} / \mathrm{L}$ and $30 \mu \mathrm{mol} / \mathrm{L} \mathrm{NA}$ at $37^{\circ} \mathrm{C}$ for $2 \mathrm{hr}$ and the fluorescent spectra were scanned by excitation at $480 \mathrm{~nm}$ and emission at 500-600 $\mathrm{nm}$.

confirming the insertion of fused recA promoter-egfp in the plasmid. The inserts were further characterized by sequencing both strands of the vectors in the regions between the upstream primer site of $r e c A$ promoter and $\mathrm{T} 7$ terminator primer site. The sequence of $r e c A$ promoter inserted into the $\mathrm{pET}-16 \mathrm{~b}:: \mathrm{P}_{\mathrm{T} 7^{-}}::$PrecA vector showed $99.20 \%$ similarity to the recA promoter from the $E$. coli ER2925 genome DNA sequence and the right direction (Fig. S2). A fragment in the sequence of recA promoter has been found previously to enhance protein translation in the E. coli cells (Thanaraj and Pandit, 1989). Moreover, the key fragment of cloned recA promoter (TATA box and RBS) is $100 \%$ homology with the recA promoter from the genome of $E$. coli ER2925 strain. The sequence of $e g f p$ gene inserted into the $\mathrm{pET}-16 \mathrm{~b}:: \mathrm{P}_{\mathrm{T} 7^{-}}:: \mathrm{Prec} A$ vector showed $99.88 \%$ homology to the egfp gene from the pEGFP-C1 plasmid (omitting the primer modifications containing the restriction sites) and the right direction (Fig. S3).

In order to confirm whether the fused recA promoteregfp gene can be correctly expressed and functioned, the E. coli BL21(DE3)/pETPrecAegfp5 (B5 strain) was first induced by a well-known DNA damaging agent nalidixic acid (NA), which can cause DNA strand break by inhibition of bacterial DNA topoisomerase II and prevention of DNA replication (Newmark et al., 2005). Then the fluorescence spectra of untreated and treated B5 cells were scanned. In contrast with untreated B5 cells, the fluorescence intensity of B5 strain cells treated by NA increased sharply with the increase of NA concentrations (Fig. 3b). All these results indicate that recA promoter inserted into the plasmid can respond to substantial DNA damage and the fused egfp gene is under the control of recA promoter, leading to highly elevated expression of EGFP protein in SOS response.

\subsection{Detection of toxicity of chemicals by $\mathrm{B5}$ strain cells}

Figure 4 confirms that B5 cells demonstrated elongation morphology contrast with untreated B5 cells through 2 $\mu \mathrm{mol} / \mathrm{L}$ NA treatment at $37^{\circ} \mathrm{C}$ and $2 \mathrm{hr}$ at $130 \mathrm{r} / \mathrm{min}$. The E. coli cells stopped cellular septation and formed filament as a consequence of the SOS response to DNA damage (Huisman et al., 1984). Therefore, we can conclude that B5 cells triggered SOS response to NA treatment which caused substantial DNA damage to B5 cells. At the same time, B5 cells which were treated by $10 \mathrm{mmol} / \mathrm{L}$ phenol (a negative control), did not show significant cellular filament (data not shown).

For toxicity detection, the treated cells were scanned immediately after induction for recording the fluorescence spectra and optical density in 96-well plate in a microplate reader at room temperature. When B5 cells were treated by various concentrations of nalidixic acid and phenol, the induction factor and optical density ratio $\left(\mathrm{OD}_{x} / \mathrm{OD}_{0}\right)$ curves were surveyed to identify the toxicity of the two chemicals to our constructed biosensor. As it was identified by Quillardet and Hofnung (1993), if the value of $F_{\mathrm{i}}$ reaches 2 or more at any concentrations, it means the tested compounds were considered to be DNA damaging agents or genotoxic. And it was shown in Fig. 5 that the values of $F_{\mathrm{i}}$ of nalidixic acid which can cause DNA strand break by inhibition of DNA replication were over 2 since the induction concentration of $1.83 \mu \mathrm{mol} / \mathrm{L}$, at which the fluorescence intensity doubled contrast with the background fluorescence intensity. The low limit of detection $(1.83 \mu \mathrm{mol} / \mathrm{L})$ of $\mathrm{B} 5$ strain to nalidixic acid was lower than that of reported biosensors $(3.57 \mu \mathrm{mol} / \mathrm{L}$ in Kostrzynska et al., 2002 and $4.6 \mu \mathrm{mol} / \mathrm{L}$ in Ptitsyn et al., 1997). During the tested concentration from 0.1 to 8.0 $\mu \mathrm{mol} / \mathrm{L}$ of nalidixic acid, the ratio of optical density of treated B5 cells declined with the increase of induction concentration, demonstrating a significant cytotoxicity to B5 cells. With $8 \mu \mathrm{mol} / \mathrm{L}$ nalidixic acid treatment, B5 cells had a cell viability of $59.4 \%$. When B5 cells were treated by phenol, which was reported to target protein only, the induction factors never exceeded value of 2 even at $10 \mathrm{mmol} / \mathrm{L}$ of induction concentration, demonstrating the 

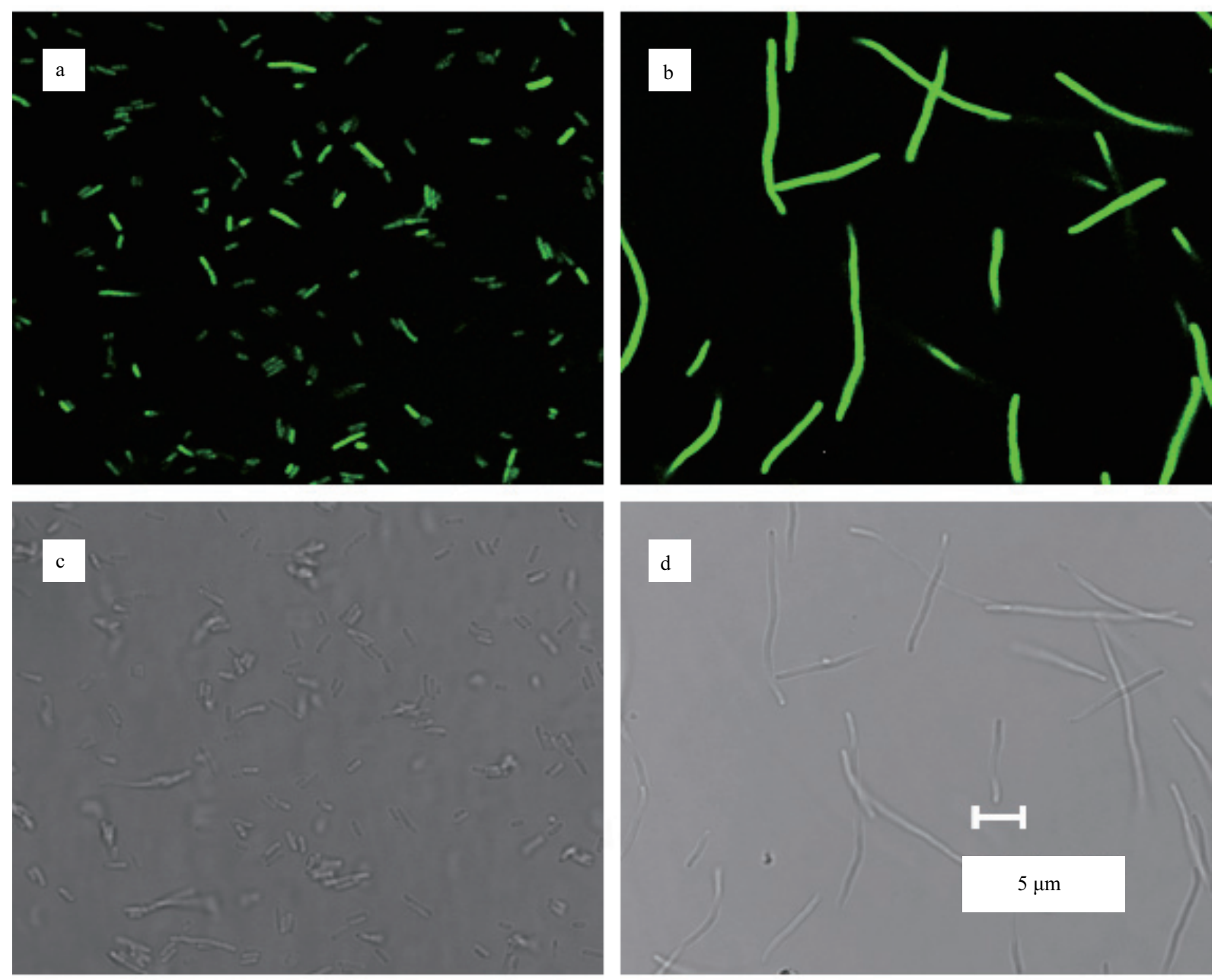

Fig. 4 Microscopic photos of B5 cells with nalidixic acid treatment. The B5 cells were imaged by confocal laser-scanning microscopy immediately after induction. The cells were not induced (a), or induced by $2 \mu \mathrm{mol} / \mathrm{L} \mathrm{NA}$ (b) at $37^{\circ} \mathrm{C}$ for $2 \mathrm{hr}$ at $130 \mathrm{r} / \mathrm{min}$. The corresponding images at bright field are shown in (c) and (d), respectively.
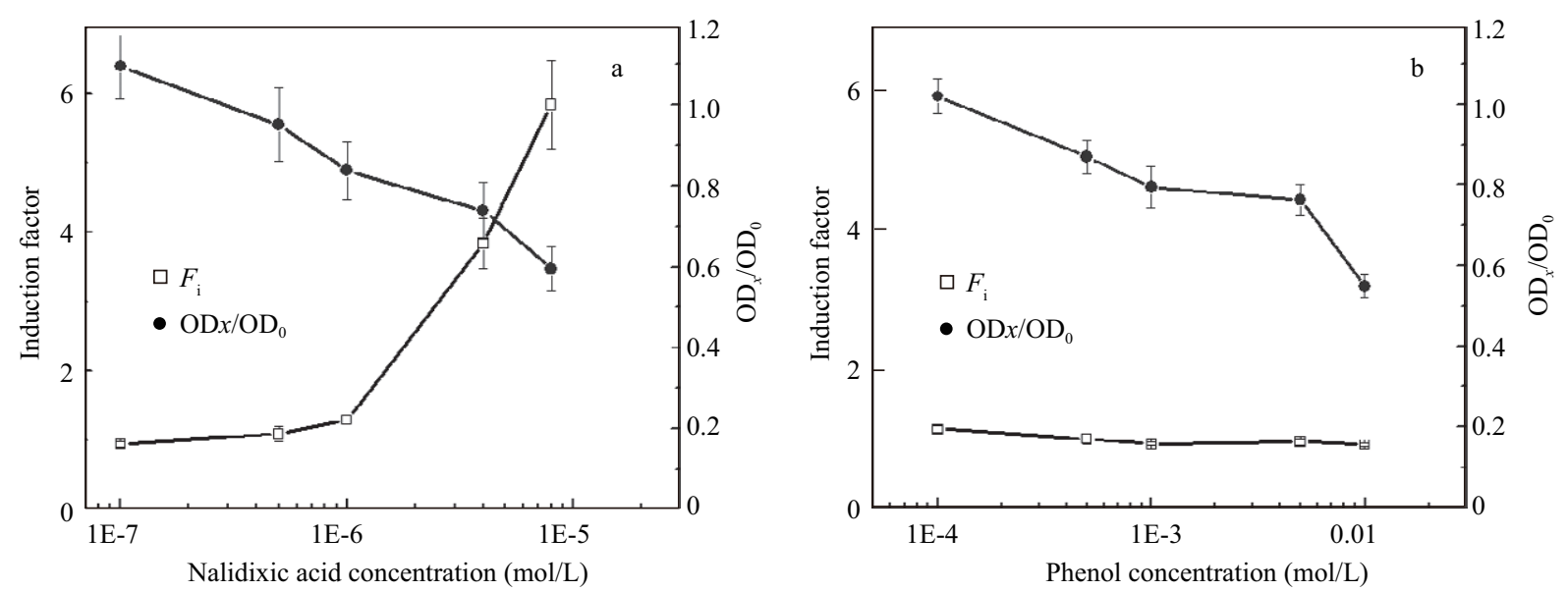

Fig. 5 Response of B5 strain to DNA damaging nalidixic acid and DNA damage-irrelevant chemical phenol. The induction factor $\left(F_{\mathrm{i}}\right)$ curves and the optical density ratio $\left(\mathrm{OD}_{x} / \mathrm{OD}_{0}\right)$ curves of SOS-EGFP test using B5 cells to nalidixic acid (a) and phenol (b). Experiments were performed at least three times, and the standard errors between the experiments were determined.

irrelevant ability of DNA-damaging. At the same time, phenol had cytotoxicity to our biosensor during the tested concentration from $100 \mu \mathrm{mol} / \mathrm{L}$ to $10 \mathrm{mmol} / \mathrm{L}$. In conclude, B5 strain biosensor could respond to genotoxin nalidixic acid for both genotoxicity and cytotoxicity, while showed only cytotoxicity to non-genotoxin phenol.

\subsection{Applications of SOS-EGFP test}

The constructed B5 strain which contained fused recA promoter-egfp gene was further applied to evaluation and screening of DNA damaging agents. The B5 cells were incubated to $\log$ phase and aliquots of culture were suffered 
from chemical treatment for $2 \mathrm{hr}$ at $130 \mathrm{r} / \mathrm{min}$ at $37^{\circ} \mathrm{C}$.

Other genotoxins, including $\mathrm{MMC}, \mathrm{MNNG}, \mathrm{CH}_{2} \mathrm{O}$ and $\mathrm{H}_{2} \mathrm{O}_{2}$ which caused DNA damage by different mechanism (Table S2), were tested using our B5 biosensor cells. The induction factors of B5 cells displayed dose-dependent response to these DNA damaging agents (Fig. 6a), manifesting its potential for detecting a large mount of chemicals with different DNA-damaging mechanism. This is consistent with the previous bacterial biosensors (Ptitsyn et al., 1997; Kostrzynska et al., 2002), further demonstrating the reliability of our constructed biosensor. These genotoxins showed a dose-response relationship with the increase of induction concentrations. In the tested concentrations of the genotoxins, $\mathrm{H}_{2} \mathrm{O}_{2}$ showed a induction factor decrease at higher concentration, indicating at which the cytotoxicity effect exceeded the genotoxicity effect to the B5 cells.

The concentrations of low limit of detection were varied from nanomolar (MMC) to micromolar (MNNG and NA) or millimolar $\left(\mathrm{CH}_{2} \mathrm{O}\right.$ and $\left.\mathrm{H}_{2} \mathrm{O}_{2}\right)$ concentrations, which were several orders of magnitude lower than that of practical dosages (Table S2). These results indicated that the constructed B5 strain could sensitively respond to the DNA damaging agents at low dose. In contrast, the typical non-genotoxic chemicals without DNA damaging potency (Table S3), including acetone, $n$-butanol, phenol and kanamycin, got the $F_{\mathrm{i}}$ values of less than 2 even at high concentrations. These non-genotoxic chemicals failed to induce SOS response in B5 cells (Fig. 6a), confirming the specificity of the B5 test against DNA damaging agents. Note the response of B5 cells to kanamycin. Although as a aminoglycoside antibiotic kanamycin can not damage DNA structure, kanamycin inhibits the expression of proteins in bacteria. Kanamycin could trigger the induction process to a value of near 2 at induction concentration of $50 \mu \mathrm{mol} / \mathrm{L}$. That is because kanamycin could induce the expression of RecA protein by the increase of "alarmone" synthesis which played the "trigger" role in derepression of SOS-operon (Kiselev, 1987).

The $\mathrm{OD}_{x} / \mathrm{OD}_{0}$ value represents the percentage of survived cells (cell viability) after chemical treatment.
Though dead or non-dividing cells also contribute to optical density, the value of $\mathrm{OD}_{x} / \mathrm{OD}_{0}$ can display the cytotoxic potential of tested chemicals. Whatever to the known genotoxins or to the negative chemicals, all the tested chemicals in the tested concentration with an exception of acetone could cause a sharply decline in the value of $\mathrm{OD}_{x} / \mathrm{OD}_{0}$ with the increasing concentration (Fig. 6b), indicating most of tested chemicals had cytotoxic effect to $\mathrm{B} 5$ strain cells. The values of $\mathrm{OD}_{x} / \mathrm{OD}_{0}$ of our $\mathrm{B} 5$ cells, which were 0.51 (to $0.5 \mu \mathrm{mol} / \mathrm{L} \mathrm{MMC),} 0.31$ (to $10 \mu \mathrm{mol} / \mathrm{L}$ $\mathrm{MNNG}$ ) and 0.63 (to $1 \mathrm{mmol} / \mathrm{L} \mathrm{CH}_{2} \mathrm{O}$ ), demonstrated a much lower value than that of the E. coli C600 (pPLS1) cells, a bacterial biosensor constructed in SOS lux test (Ptitsyn et al., 1997), which were 0.88 (to $1 \mu \mathrm{mol} / \mathrm{L} \mathrm{MMC),}$ 0.94 (to $10 \mu \mathrm{mol} / \mathrm{L} \mathrm{MNNG}$ ) and 0.80 (to $1 \mathrm{mmol} / \mathrm{L} \mathrm{CH}_{2} \mathrm{O}$ ). Our SOS-EGFP bacterial biosensor was more sensitive than the SOS lux bacterial biosensor against the relative optical density $\left(\mathrm{OD}_{x} / \mathrm{OD}_{0}\right)$.

Despite of no observation of DNA damage caused by them, it is interesting that these non-genotoxic chemicals display detectable cytotoxicity, consistent with their target at proteins in organisms (Fig. 6b). These chemicals cannot react with DNA, and therefore cause no DNA damage in the SOS-EGFP test strain. Therefore, these chemicals will only display cytotoxicity in the B5 strain but no genotoxicity. These results further prove that the chemical caused cytotoxicity of B5 strain cannot interfere with the measurement of the DNA damage effect, e.g., especially for SOS response to DNA damage.

This observation indicates the constructed B5 strain can be used to test cytotoxicity of the chemicals while measuring the DNA damage potency. Due to simultaneous test on DNA damage related genotoxicity and DNA damageindependent cytotoxicity, B5 strains may be potentially useful to evaluate the relative potency of chemicals in genotoxicity and cytotoxicity.

The SOS-EGFP test using our B5 biosensor, had the advantages of SOS-reporter genotoxicity/mutagenesis test. For example, it provided a detection method in vivo not disturbing the living cells and in a short time $(2 \mathrm{hr})$; large scale of chemicals with different mechanisms to damage
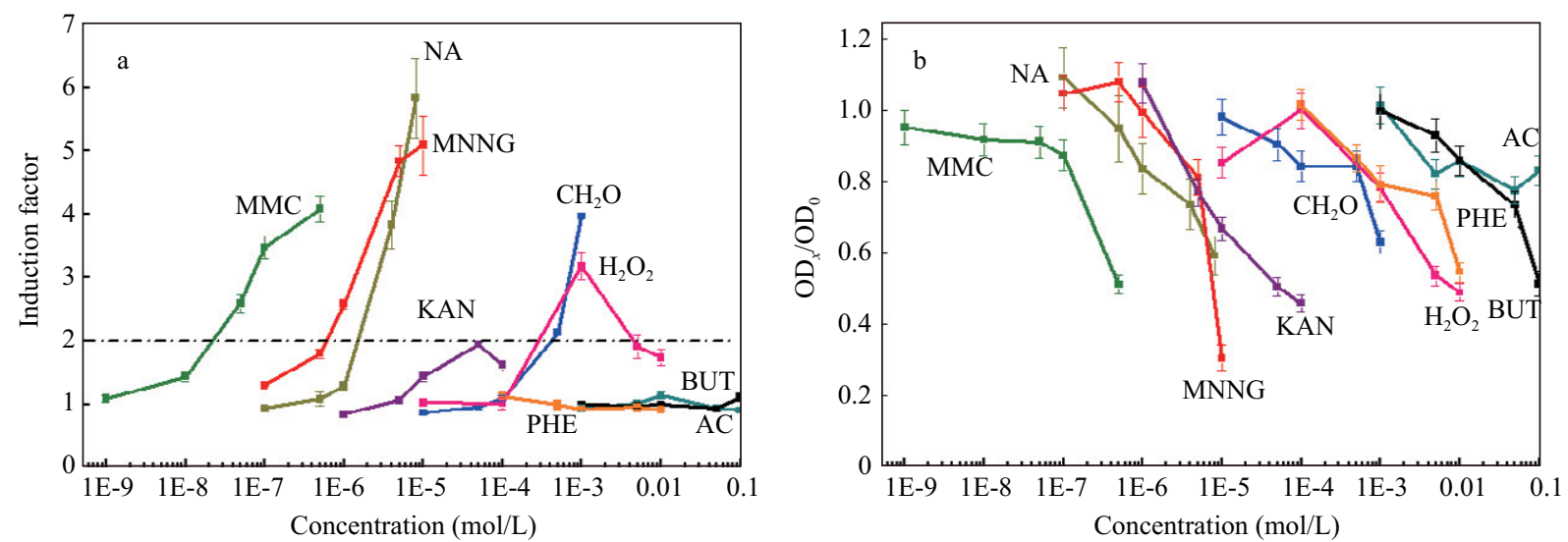

Fig. 6 Response of B5 strain to DNA damaging genotoxins and DNA damage-irrelevant chemicals. (a) the induction factor $\left(F_{\mathrm{i}}\right)$ curves of SOS-EGFP (B5 cells) test; (b) the optical density ratio $\mathrm{OD}_{x} / \mathrm{OD}_{0}$ of $\mathrm{B} 5$ cells. Experiments were performed at least three times, and the standard errors between the experiments were determined. DNA damaging genotoxins: MMC: mytomycin C, MNNG: N-methyl-N'-nitro-N-nitrosoguanidine, NA: nalidixic acid, $\mathrm{H}_{2} \mathrm{O}_{2}$ : hydrogen peroxide, $\mathrm{CH}_{2} \mathrm{O}$ : formaldehyde. DNA damage-irrelevant chemicals (negetive controls): AC: acetone, BUT: $n$-butanol, PHE: phenol, KAN: kanamycin. 
DNA can be detected by the same strain comparing with Ames test which need lots of strains to detect specific kind of chemicals (Ames, 1979). In SOS-reporter systems, SOS lux test needs substrate addition for the chemical luminescence detection. And when a wide range of chemicals needed detection, the cost of the SOS lux test will enhance significantly; and this will restrict the practical application of SOS lux test (Ptitsyn et al., 1997). SOS-GFPmut3 test (Kostrzynska et al., 2002) used the mutant of wild type GFP, GFPmut3, as a reporter which could emit brighter fluorescence than the wild type GFP. However, sensitive detection of DNA-damaging agents was obtained needing another incubation at $4{ }^{\circ} \mathrm{C}$ for $2 \mathrm{hr}$ to get matured and fluorescent GFPmut3 after induction process of $90 \mathrm{~min}$. Our biosensor using B5 strain needs no other substrate and more time to mature the fluorescent chromophore without loss of sensitivity and specificity.

\section{Conclusions}

Here we demonstrated the construction of a sensitive and specific bacterial biosensor (B5 strain) for detection of DNA damage and DNA damaging agents. It expects that the constructed biosensor can be potentially useful to detect and screen environmental carcinogen and anti-cancer drugs. Interestingly, the constructed biosensor is probably useful to simultaneously evaluate the genotoxicity and cytotoxicity.

\section{Acknowledgments}

This work was supported by the National Natural Science Foundation of China (No. 20707034, 20877091, 20890112, 20921063), and the National Basic Research Program (973) of China (No. 09CB421605, 2010CB933500, 2011CB936001).

\section{Supplementary data}

Supplementary data associated with this article can be found in the online version.

\section{References}

Ames B N, 1979. Identifying environmental chemicals causing mutations and cancer. Science, 204(4393): 587-593.

Arshad R, Farooq S, Ali S S, 2010. Effect of mutations induced by $\mathrm{N}$-methyl-N'-nitro-N-nitrosoguanidine on expression of penicillin $\mathrm{G}$ acylase and $\beta$-lactamase in wild-type Escherichia coli strains. Annals of Microbiology, 60(4): 645-652.

Cabanne C, Noubhani A M, Hocquellet A, Dole F, Dieryck W, Santarelli X, 2005. Purification and on-column refolding of EGFP overexpressed as inclusion bodies in Escherichia coli with expanded bed anion exchange chromatography. Journal of Chromatography B, 818(1): 23-27.

Cooke M S, Rozalski R, Dove R, Gackowski D, Siomek A, Evans MD et al., 2006. Evidence for attenuated cellular 8-oxo7,8-dihydro-2'-deoxyguanosine removal in cancer patients. Biological Chemistry, 387(4): 393-400.

Cormack B P, Valdivia R H, Falkow S, 1996. FACS-optimized mutants of the green fluorescent protein (GFP). Gene,
173(1): 33-38.

Doughty D, 1990. The process of wound healing: a nursing perspective. Progressions Develop Ostomy Wound Care, 2: 3-12.

Dunn B P, Black J J, Maccubbin A, 1987. ${ }^{32}$ P-postlabling analysis of aromatic DNA adducts in fish from polluted areas. Cancer Research, 47(24): 6543-6548.

Feng F, Wang X L, Yuan H C, Wang H L, 2009. Ultraperformance liquid chromatography-tandem mass spectrometry for rapid and highly sensitive analysis of stereoisomers of benzo[a]pyrene diol epoxide-DNA adducts. Journal of Chromatography B Analytical Technologies in the Biomedical and Life Sciences, 877(22): 2104-2112.

Feng F, Yin J F, Song M Y, Wang H L, 2008. Preparation, identification and analysis of stereoisomeric anti-benzo[a]pyrene diol epoxide-deoxyguanosine adducts using phenyl liquid chromatography with diode array, fluorescence and tandem mass spectrometry detection. Journal of Chromatography A, 1183(1-2): 119-128.

Friedberg E C, Walker G C, Siede W, Wood R D, Schultz R A, Ellenberger T, 2006. DNA Repair and Mutagenesis (2nd ed.). ASM Press, Washington, D.C.

Funk D, Sorg B L, Lindner S C, Schmeiser H H, 2010. ${ }^{32} \mathrm{P}$-postlabeling analysis of DNA adducts formed by leukotriene $\mathrm{A}_{4}\left(\mathrm{LTA}_{4}\right)$. Environmental and Molecular $\mathrm{Mu}$ tagenesis, 51(4): 338-343.

Hamza A H, Nasr M M, Deghady A A, 2005 The use of mitomycin-C for respiratory papillomas: Clinical, histologic and biochemical correlation. Saudi Medical Journal, 26(11): 1737-1745.

Heim R, Cubitt A B, Tsien R Y, 1995. Improved green fluorescence. Nature, 373(6516): 663-664.

Huisman O, D'Ari R, Gottesman S, 1984. Cell-division control in Escherichia coli: specific induction of the SOS function SfiA protein is sufficient to block septation. Proceedings of the National Academy of Sciences, USA, 81(14): 44904494.

Kiselev V I, 1987. Kanamycin sulfate-an inducer of recA gene in Escherichia coli. Molekuliarnaia Genetika, Mikrobiologiia I Virusologiia, (9): 41-44.

Kostrzynska M, Leung K T, Lee H, Trevors J T, 2002. Green fluorescent protein-based biosensor for detecting SOS-inducing activity of genotoxic compounds. Journal of Microbiological Methods, 48(1): 43-51.

Mersch-Sundermann V, Schneider U, Klopman G, Rosenkranz H S, 1994. SOS induction in Escherichia coli and Salmonella mutagenicity: a comparison using 330 compounds. Mutagenesis, 9(3): 205-224.

Miller J H, 1972. Experiments in Molecular Genetics. Cold Spring Harbor Laboratory Press, Cold Spring Harbor, New York.

Nelson D L, Cox M M, 2005. Lehninger: Principles of Biochemistry (4th ed.). W.H. Freeman and Company, New York, 1098.

Newmark K G, O’Reilly E K, Pohlhaus J R, Kreuzer K N, 2005 Genetic analysis of the requirements for SOS induction by nalidixic acid in Escherichia coli. Gene, 356: 69-76.

Norman A S, Hansen L H, Sørensen S J, 2005. Construction of a ColD $c d a$ promoter-based SOS-green fluorescent protein whole-cell biosensor with higher sensitivity toward genotoxic compounds than constructs based on recA, umuDC, or sulA promoters. Applied and Environment Microbiology, 71(5): 2338-2346.

Ohe T, Watanabe T, Wakabayashi K, 2004. Mutagens in surface 
waters: a review. Mutation Research, 567(2-3): 109-149.

Park S, You X J, Imlay J A, 2005. Substantial DNA damage from submicromolar intracellular hydrogen peroxide detected in $\mathrm{Hpx}^{-}$mutants of Escherichia coli. Proceedings of the National Academy of Sciences, USA, 102(26): 9317-9322.

Ptitsyn L R, Horneck G, Komova O, Kozubek S, Krasavin E A, Bonev $\mathrm{M}$ et al., 1997. A biosensor for environmental genotoxin screening based on an SOS lux Assay in recombinant Escherichia coli cells. Applied and Environmental Microbiology, 63(11): 4377-4384.

Quillardet P, Hofnung M, 1993. The SOS chromotest: a review. Mutation Research, 297(3): 235-279.

Risom L, Møller P, Vogel U, Kristjansen P E G, Loft S, 2003. $\mathrm{X}$-ray-induced oxidative stress: DNA damage and gene expression of HO-1, ERCC1 and OGG1 in mouse lung. Free Radical Research, 37(9): 957-966.

Rodríguez-Ariza A, Alhama J, Díaz-Méndez FM, López-Barea J, 1999. Content of 8-oxodG in chromosomal DNA of Sparus aurata fish as biomarker of oxidative stress and environmental pollution. Mutation Research, 438(2): 97 107.

Sambrook J, Russell D W, 2001. Molecular Cloning: A Laboratory Manual (3rd ed.). Cold Spring Harbor, New York.
Thanaraj T A, Pandit M W, 1989. An additional ribosomebinding site on mRNA of highly expressed genes and a bifunctional site on the colicin fragment of 16S rRNA from Escherichia coli: important determinants of the efficiency of translation-initiation. Nucleic Acids Research, 17(8): 29732985.

Verkhusha V V, Otsuna H, Awasaki T, Oda H, Tsukita S, Ito K, 2001. An enhanced mutant of red fluorescent protein DsRed for double labeling and developmental timer of neural fiber bundle formation. Journal of Biological Chemistry, 276(32): 29621-29624.

Vollmer A C, Belkin S, Smulski D R, Van dyk T K, Larossa R A, 1997. Detection of DNA damage by use of Escherichia coli carrying recA'::lux, uvrA'::lux, or alkA'::lux reporter plasmids. Applied and Environmental Microbiology, 63(7): 2566-2571.

Wang Z X, Lu M L, Wang X L, Yin R C, Song Y L, Le X C et al., 2009. Quantum dots enhanced ultrasensitive detection of DNA adducts. Analytical Chemistry, 81(24): 10285-10289.

Wang Z X, Wang X L, Liu S Q, Yin J F, Wang $\mathrm{H}$ L, 2010. Fluorescently imaged particle counting immunoassay for sensitive detection of DNA modifications. Analytical Chemistry, 82(23): 9901-9908. 